\title{
A COMPARATIVE STUDY ON THE OBSTETRIC OUTCOME WITH INCREASING AGE IN PRIMIGRAVIDAE
}

\author{
Smitha D'Couth'1, Jayasree Sukumarapillai², Sajala Vimalraj ${ }^{3}$
}

${ }^{1}$ Associate Professor, Department of Obstetrics and Gynaecology, Government Medical College, Kozhikode. ${ }^{2}$ Assistant Professor, Department of Obstetrics and Gynaecology, Government Medical College, Kozhikode. ${ }_{3}^{3}$ Additional Professor, Department of Obstetrics and Gynaecology, Government Medical College, Kozhikode.

\begin{abstract}
The prevalence of elderly primigravidae is on an increasing trend due increasing infertility and delay in child bearing. These women with advanced age are considered to be at high risk of pregnancy complications and adverse obstetric outcome. This has led to increasing antepartum surveillance and increased interventions including induction of labour and caesarean section.
\end{abstract}

\section{OBJECTIVES}

To analyse the maternal and foetal complications and obstetric outcome in primigravidae above 30 years with those between 20 and 29 years of age.

\section{MATERIALS AND METHODS}

A one-year retrospective case control study where the birth outcome of elderly primigravidae above 30 years was compared with younger primigravidae (20-29 years) delivered at the Govt. Medical College, Kozhikode.

\section{RESULTS}

During the study period there were 13459 deliveries of which 392 patients were above the 30 years of age. Antepartum complications like hypertensive disorders, GDM, placenta praevia and preterm labour were increased in elderly patients. The caesarean section rate and low birth weight was found to be high with increasing age.

\section{CONCLUSION}

In spite of increased risk of maternal and neonatal complications in elderly primigravidae, the obstetric outcome was good.

\section{KEYWORDS}

Elderly Primigravidae, Obstetric Outcome, Caesarean Section.

HOW TO CITE THIS ARTICLE: D'Couth S, Sukumarapillai J, Vimalraj S. A comparative study on the obstetric outcome with increasing age in primigravidae. J. Evolution Med. Dent. Sci. 2016;5(75):5573-5577, DOI: 10.14260/jemds/2016/1259

\section{INTRODUCTION}

Maternal age has been an important factor in the survival of mankind. When life expectancy was only up to the fourth or fifth decade and women had no control over fertility, they had no choice but to bear children as teenagers and young adults. In recent times, women have changed their lifestyle in the pursuit of higher education and professional and socioeconomic stability. Consequently, this has led to postponement of child bearing, resulting in an increasing maternal age at first pregnancy.

The definition set by the Council of International Federation of Obstetrics stated "An elderly primigravida is one 35 years or more at the first delivery." Regardless of the age specific definition, it is well established that advancing maternal age is associated with chromosomal abnormalities, sub-fertility, chronic medical illness and fibroids. Maternal age being a risk indicator for many antenatal complications, there is an increase in antepartum surveillance and increased interventions like induction of labour and caesarean section in

Financial or Other, Competing Interest: None.

Submission 11-08-2016, Peer Review 04-09-2016,

Acceptance 10-09-2016, Published 19-09-2016.

Corresponding Author:

Dr. Smitha D'Couth,

Manasa, Behind Kirtads,

Chevayur P. O.,

Kozhikode, Kerala-673017.

E-mail: smithasebin@gmail.com

DOI: $10.14260 /$ jemds $/ 2016 / 1259$ elderly pregnant women. A large body of literature exists describing the impact of advanced maternal age on maternal and foetal outcomes. Unfortunately, these data have conflicting results. For instance, a few studies have found an association between delaying child birth and poor pregnancy outcomes while other studies challenge these findings. The purpose of this study is to evaluate the maternal and foetal complications and obstetric outcome with increasing maternal age in primigravidae.

\section{OBJECTIVE}

To analyse the risks of maternal and foetal complications and obstetric outcome with increasing maternal age in primigravidae.

\section{MATERIALS AND METHODS}

It was a retrospective case control study with data being collected from parturition registers, maternal \& neonatal charts. Study population contained primigravidae of 30 years and above delivered in the Department of OB-GYN, Govt. Medical College, Kozhikode from $1^{\text {st }}$ July 2012 to $30^{\text {th }}$ June 2013. As per definition, elderly primigravidae are those above the age of 35 years. Since our institute caters to a population where early marriage and delivery is the accepted norm, those above 30 years with first pregnancy were included in the study. Those with a previous abortion or obstetric mishap having no living children, now delivering above 30 years of age were excluded. For each patient in the study group, two primigravidae with age of 20-29 years delivering subsequently were taken as control. 
The patients in study group were divided into 3 groups according to the maternal age at delivery. Group A: 30-34 years; Group B: 35-39 years and Group C: 40 years and above. Comparison of total study group with controls and then each subgroup with controls were done. Maternal factors compared included pre-existing complications extending into pregnancy (Like chronic hypertension, overt diabetes, thyroid dysfunction and fibroids) complications due to pregnancy (Hypertensive disorders, gestational diabetes, IUGR, placenta praevia, abruptio placenta and malpresentations). The events of labour including the gestational age at delivery, induction and the mode of delivery and the indications for CS and intrapartum \& postpartum complications were reviewed. Neonatal factors compared were the birth weight, Apgar score, congenital anomalies and perinatal mortality. Statistical significance of the data was assessed by the Chi-square test considering $\mathrm{p}$-value less than 0.05 as significant.

\section{RESULTS}

Total number of deliveries during the study period was 13459 of which 6734 were primigravidae. A total of 392 patients were of age 30 years or above and were included in the study. This comprised of $2.91 \%$ of all deliveries and $5.82 \%$ of total primigravidae (6734).
There were 269 patients in Group A (30-34 years); 112 in Group B (35-39 years); and 11 patients in Group C (40 years or above). There were no patients above 45 years of age. 784 primigravidae between 20-29 years were taken as control group.

When the pre-existing maternal complications were analysed, there was an increased incidence of chronic hypertension, pre-gestational diabetes mellitus, hypothyroidism and fibroids in the study population than in the control group which was statistically significant. (Table: 1 ).

\begin{tabular}{|c|c|c|c|}
\hline $\begin{array}{c}\text { Pre-existing } \\
\text { Complications }\end{array}$ & $\begin{array}{c}\text { Study } \\
\text { Group } \\
(\mathrm{n}=392)\end{array}$ & $\begin{array}{c}\text { Control } \\
\text { Group } \\
(\mathrm{n}=784)\end{array}$ & P value \\
\hline $\begin{array}{c}\text { Chronic } \\
\text { Hypertension }\end{array}$ & $8(2.04 \%)$ & $2(0.26 \%)$ & 0.003 \\
\hline Overt Diabetes & $10(2.55 \%)$ & 0 & 0.00002 \\
\hline Hypothyroidism & $10(2.55 \%)$ & $4(0.51 \%)$ & 0.004 \\
\hline Fibroids & $22(5.61 \%)$ & $1(0.13 \%)$ & 0.0000001 \\
\hline \multicolumn{2}{|l|}{ Table 1: Pre-existing Complications } \\
\hline
\end{tabular}

The comparison of the pre-existing complications in each study group with the controls is shown in Table: 2

\begin{tabular}{|c|c|c|c|c|}
\hline Pre-existing Complications & $\begin{array}{c}\text { Control } \\
\text { Group } \\
\mathrm{n}=784\end{array}$ & $\begin{array}{c}\text { Group A } \\
(30-34 \text { yrs. }) \\
n=269\end{array}$ & $\begin{array}{c}\text { Group B } \\
\text { (35-39 yrs.) } \\
n=112\end{array}$ & $\begin{array}{c}\text { Group C } \\
\text { (40 yrs. and above) } \\
n=11\end{array}$ \\
\hline Chronic Hypertension & 2 & $\begin{array}{c}4(p-0.04) \\
R R-5.83\end{array}$ & $\begin{array}{c}4(p-0.003) \\
R R-14\end{array}$ & $0(\mathrm{p} 0.972)$ \\
\hline Overt Diabetes & 0 & $4(p-0.04)$ & $6(p-0.000003)$ & 0 \\
\hline Hypothyroidism & 4 & $\begin{array}{c}6(p-0.02) \\
R R-4.37\end{array}$ & $\begin{array}{c}4 \text { (p 0.011) } \\
\text { RR -7 }\end{array}$ & $0(\mathrm{p} 0.946)$ \\
\hline Fibroids & 1 & $\begin{array}{c}13(\mathrm{p}-0.00002) \\
\mathrm{RR}-37.89\end{array}$ & $\begin{array}{c}9(p-0.0000001) \\
\text { RR }-63\end{array}$ & $0(\mathrm{p} 0.986)$ \\
\hline
\end{tabular}

The relative risk of having chronic hypertension was 5.83 in 30-34 yrs. age group which increased to 14 in $35-39$ yrs. Similarly hypothyroidism and fibroids also showed an increased relative risk in 35-39 yrs. group than in 30-34 yrs. group. But, none of these complications were present in 40 yrs. and above group.

\begin{tabular}{|c|c|c|c|}
\hline Obstetric Complications & $\begin{array}{c}\text { Study Group } \\
\mathbf{n = 3 9 2}\end{array}$ & $\begin{array}{c}\text { Control Group } \\
\mathbf{n = 7 8 4}\end{array}$ & P value \\
\hline PIH & $87(22.19 \%)$ & $84(10.71 \%)$ & 0.0000001 \\
\hline GDM & $50(12.76 \%)$ & $28(3.57 \%)$ & 0.0000001 \\
\hline Preterm Labour & $27(6.89 \%)$ & $32(4.08 \%)$ & 0.0004 \\
\hline PPROM & $12(3.06 \%)$ & $16(2.04 \%)$ & $>0.05$ (not significant) \\
\hline Placenta Praevia & $9(2.3 \%)$ & $2(0.25 \%)$ & $>001$ \\
\hline Abruption & $4(1.02 \%)$ & $9(1.14 \%)$ & $>0.05$ (not significant) \\
\hline Malpresentation & $21(5.36 \%)$ & $33(4.21 \%)$ & $>0.05$ (not significant) \\
\hline Multiple pregnancy & $5(1.3 \%)$ & $14(1.79 \%)$ & $>0.05$ (not significant) \\
\hline Anaemia & $96(24.49 \%)$ & $201(25.63 \%)$ & \\
\hline
\end{tabular}

Obstetric complications like hypertensive disorders (22.19\% vs. 10.71\%), GDM (12.76\% vs. 3.57\%), placenta praevia ( $2.3 \%$ vs. $0.25 \%$ ) and preterm delivery (6.89 vs. $4.08 \%$ ) showed a significant increase in study population when compared with the control group (Table: 3). Abruptio placentae (1.02\% vs. $1.14 \%$ ) and multiple pregnancy (1.3\% vs. $1.79 \%)$ in study group was similar to that of control population. Malpresentations (5.36\% vs. $4.21 \%$ ) showed a minimal increase in study group which was not statistically significant. Anaemia (24.49\% vs. 25.63.\%) in study population was less than control group. 


\begin{tabular}{|c|c|c|c|c|}
\hline $\begin{array}{c}\text { Obstetric } \\
\text { Complications }\end{array}$ & $\begin{array}{c}\text { Control Group } \\
n=784\end{array}$ & $\begin{array}{c}\text { Group A } \\
\text { (30-34 yrs.) } \\
\text { n = 269 }\end{array}$ & $\begin{array}{c}\text { Group B } \\
(35-39 \text { yrs.) } \\
n=112 \\
\end{array}$ & $\begin{array}{c}\text { Group C } \\
\text { (40 yrs. and above) } \\
n=11\end{array}$ \\
\hline $\mathrm{PIH}$ & $84(10.71 \%)$ & $\begin{array}{c}52(19.33 \%) \\
\mathrm{RR}-1.8(1.31-2.48)\end{array}$ & $\begin{array}{c}32(28.57 \%) \\
\text { RR- } 2.67(1.87-3.81)\end{array}$ & $\begin{array}{c}3(27.27 \%) \\
\text { Not significant }\end{array}$ \\
\hline GDM & $28(3.57 \%)$ & $\begin{array}{c}27(10.04 \%) \\
\text { RR- } 2.81(1.69-4.68)\end{array}$ & $\begin{array}{c}20(17.86 \%) \\
\text { RR -5 (2.92-8.57) } \\
\end{array}$ & $\begin{array}{c}3(27.27 \%) \\
\text { RR - } 7.64(2.72-21.42) \\
\end{array}$ \\
\hline Preterm labour & $32(4.08 \%)$ & $\begin{array}{c}17(6.31 \%) \\
\text { RR }-1.61(1.1-2.35) \\
\end{array}$ & $\begin{array}{c}9(8.04 \%) \\
\text { RR -1.99(1.24-3.17) }\end{array}$ & $\begin{array}{c}1(9.09 \%) \\
\text { RR }-4.26(1.88-9.61)\end{array}$ \\
\hline PPROM & $16(2.04 \%)$ & $\begin{array}{c}7(2.36 \%) \\
\text { Not significant } \\
\end{array}$ & $\begin{array}{c}4(3.57 \%) \\
\text { Not significant }\end{array}$ & $\begin{array}{c}1(9.09 \%) \\
\text { Not significant }\end{array}$ \\
\hline
\end{tabular}

GDM and preterm labour and PPROM showed almost exponential increase with increasing age but hypertensive disorders was highest in Group B followed by group C and A respectively (Table: 4) The increasing incidence of GDM and preterm labour with advanced maternal age was statistically significant with a relative risk of GDM and preterm labour in primigravidae above 40 years being 7.64 and 4.26 respectively. Though PPROM also increased with increasing age, this was not statistically significant. Hypertensive disorders had a relative risk of 1.8 (95\% CI--1.31 -2.48) in Group A and 2.67 (95\% CI--1.87 -3.81) in Group B. 3 patients in Group A had HELLP syndrome.

Mean gestational age at delivery was 37 weeks +3 days in study population and 38 weeks +5 days in controls. Delivery at an early gestational age may be due to increased antepartum complications.

\begin{tabular}{|c|c|c|}
\hline & $\begin{array}{c}\text { No. of } \\
\text { Inductions }\end{array}$ & $\begin{array}{c}\text { No. of failed } \\
\text { Inductions }\end{array}$ \\
\hline Study Group & $85(21.68 \%)$ & $32(37.67 \%)$ \\
\hline Control Group & $288(36.73 \%)$ & $52(18.06 \%)$ \\
\hline \multicolumn{2}{|c|}{ Table 5: Induction of Labour } \\
\hline
\end{tabular}

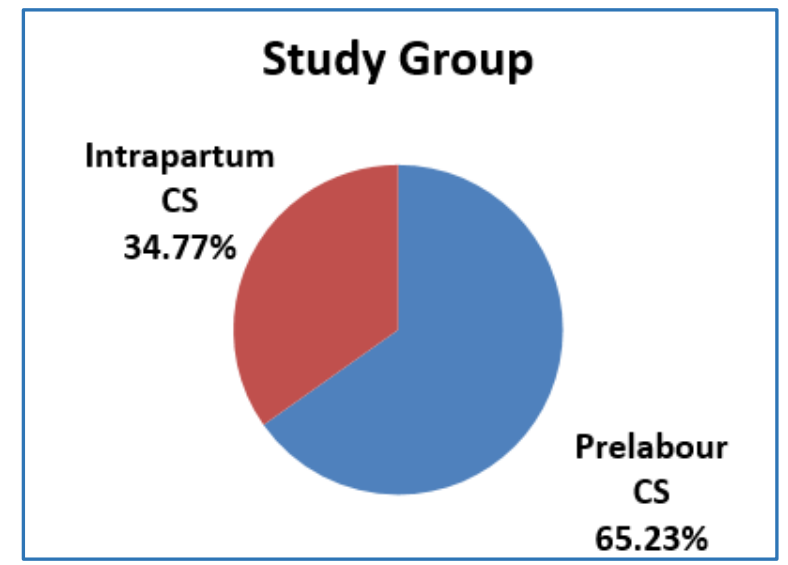

Failed induction occurred in $37.67 \%$ in whom induction of labour was done in study group and in $18.06 \%$ of those in whom labour was induced in control group (Table: 5 ).This increase in failed induction in study group was statistically significant with a $\mathrm{p}$ value of 0.0001 and relative risk of 2.09 (95\% CI -- $1.44-3.05 \%)$

\begin{tabular}{|c|c|c|c|}
\hline $\begin{array}{c}\text { Mode of } \\
\text { Delivery }\end{array}$ & $\begin{array}{c}\text { Study } \\
\text { Group }\end{array}$ & $\begin{array}{c}\text { Control } \\
\text { Group }\end{array}$ & P value \\
\hline $\begin{array}{c}\text { Vaginal } \\
\text { Delivery }\end{array}$ & $\begin{array}{c}136 \\
(34.69 \%)\end{array}$ & $\begin{array}{c}581 \\
(74.1 \%)\end{array}$ & \\
\hline $\begin{array}{c}\text { Caesarean } \\
\text { Section }\end{array}$ & $\begin{array}{c}256 \\
(65.31 \%)\end{array}$ & $\begin{array}{c}203 \\
(25.89 \%)\end{array}$ & $\begin{array}{c}0.0000001 \\
\text { RR-2.52 }(95 \% \\
\text { CI--2.2 - } 2.9)\end{array}$ \\
\hline \multicolumn{4}{|c|}{ Table 6: Mode of Delivery } \\
\hline
\end{tabular}

$65.31 \%$ of patients in study population underwent caesarean section (Table: 6 ) with a relative risk for caesarean section of 2.52 (95\% CI -- 2.2 -2.9). Of the caesarean sections in study group $65.23 \%$ were pre-labour caesarean section (Figure: 1). The relative risk for caesarean section in group A, $\mathrm{B}$ and $\mathrm{C}$ was $2.28,2.75$ and 3.62 respectively.

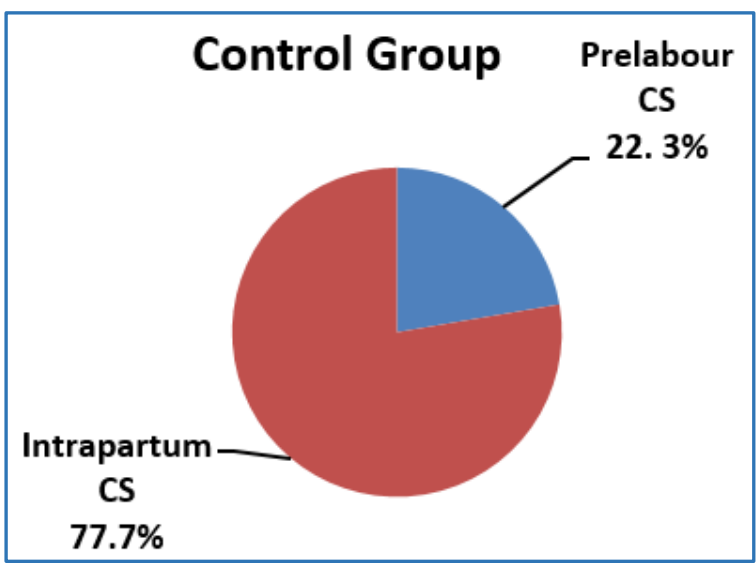

Fig. 1: Caesarean Section

On analysing the neonatal factors, low Apgar score was seen in $9.19 \%$ of neonates in study group and $5.97 \%$ of control group; but this difference was not statistically significant.

\begin{tabular}{|c|c|c|c|}
\hline $\begin{array}{c}\text { Birth } \\
\text { Weight }\end{array}$ & Study Group & Control Group & P value \\
\hline $\begin{array}{c}\text { LBW } \\
(<2.5 \mathrm{~kg})\end{array}$ & $136(34.69 \%)$ & $177(22.58 \%)$ & 0.000009 \\
\hline $\begin{array}{c}\text { VLBW } \\
(<1.5 \mathrm{~kg})\end{array}$ & $14(5.2 \%)$ & $7(0.89 \%)$ & \\
\hline \multicolumn{4}{|c|}{ Table 7: Birth Weight of Neonates } \\
\hline
\end{tabular}

Mean birth weight in the study group was $2.39 \mathrm{~kg}$ and in control group was $2.86 \mathrm{~kg}$. (Table: 7 ) with a relative risk of 1.54 (95\% CI --1.27 -1.85) in having low birth weight babies in elderly patients compared to primigravidae under 30 years. Relative risk of LBW babies in 30-34 yrs. was 1.3 (95\% CI-1.11-1.72), in 35-39 yrs. was 1.7 (95\% CI -- $1.3-2.22$ ) and 40 $\&$ above age group was 3.62 (95\% CI--2.67-4.93). Congenital anomalies were seen in $0.76 \%$ of study group and $0.64 \%$ of control group. 


\begin{tabular}{|c|c|c|}
\hline $\begin{array}{c}\text { Perinatal } \\
\text { Death }\end{array}$ & Study Group & Control Group \\
\hline IUD & $11(2.98 \%)$ & $14(1.79 \%)$ \\
\hline NND & $14(3.57 \%)$ & $15(1.91 \%)$ \\
\hline \multicolumn{2}{|c|}{ Table 8: Perinatal Mortality } \\
\hline
\end{tabular}

Perinatal mortality was seen to be high in study group, but the difference was not statistically significant ( $p$ value -0.645 ) (Table: 8).

In the study group, 4 patients $(1.02 \%)$ developed PPH while in the control group $10(1.27 \%)$ developed PPH. There were no cases of maternal mortality in both groups.

\section{DISCUSSION}

The prevalence of primigravidae above 30 yrs. (5.82\% of primi) was similar to the study by 0jule et al in Nigeria $(4.7 \%$ of primi) even though our population had an early marriage and delivery.(1) Though the pre-gestational maternal complications were more in the advanced maternal age population there was no increasing trend of these complications with age. Different studies have shown conflicting results with significant increased risk of chronic hypertension and fibroids in elderly primigravidae. $(2,3)$ while no difference in incidence of pre-gestational diabetes, chronic hypertension and chronic renal disease.(4) Incidence of obstetric complications like hypertensive disorders, GDM, placenta praevia and preterm delivery were increased in primigravidae with advanced age as in several other studies.(2,3,5,6,7) Barbara et al reported increased obstetric complications due to underlying medical disorders. (8) With abruption, malpresentation and multiple pregnancy, our results were similar to that of Yun Wang et al where there was no significant increase in preeclampsia, gestational diabetes, placenta praevia, malpresentation, abruption and preterm delivery with advanced maternal age.(4)

The higher incidence of caesarean section particularly prelabour caesarean in this study was comparable with many studies which showed significantly increasing caesarean section rate with increasing maternal age. $(5,3-9,10)$ Unlike a very recent study showing increase in induced labour and instrumental delivery in elderly mothers. ${ }^{(5)}$ our study showed less of labour inductions and instrumental delivery in elderly patients. The risk of PPH was similar in older and younger patients as against some showing higher risk of PPH. $(4,5,8,80)$ especially after vaginal delivery.(5)

IUGR and low birth weight showed an increasing trend with increasing age. $(5,8,11,12$,$) but the increase in low Apgar$ score was not significant unlike reported by other authors. $(5,10)$ Contradictory to the reports that advanced maternal age was found to be an independent predictor of still births. $(11,13,14)$ this study showed no increased risk of still births.(15) There was also no increase in the congenital malformations unlike reported. $(8,11)$ may be because the first and second trimester pregnancy losses were not included in the study. According to Salem et al and Barbara et al, there was significant linear association between advanced maternal age and perinatal mortality in nulliparous women. $(8,11)$ Despite the increased risk of complications ,in the present study, maternal and perinatal outcomes were good. $(2,4,6,16,17)$

\section{CONCLUSION}

Primigravidae 30 years and older had higher rates of antepartum, intrapartum, and neonatal complications than younger primigravidae. The higher rates of caesarean section in elderly can be attributed to the increase in antepartum complications and earlier interventions. Though maternal and neonatal morbidity is increased with advanced maternal age the obstetric outcome is not affected when managed in tertiary care centres.

\section{REFERENCES}

1. Ojule JD, Ibe VC, Fiebai PO. Pregnancy outcome in elderly primigravidae. Annals of African Medicine 2011;10 (3):204 -8.

2. Prysak M, Lorenz RP, Kisly A. Pregnancy outcome in nulliparous women 35 years and older. Obstet Gynecol 1995;85(1):65-70.

3. Jahromi BN, Husseini Z. Pregnancy outcome at maternal age 40 and older. Taiwan J Obstet Gynecol 2008; 47(3):318-21.

4. Wang Y, Tanbo T, Åbyholm T, et al. The impact of advanced maternal age and parity on obstetric and perinatal outcomes in singleton gestations. Arch Gynecol Obstet 2011;284(1):31-7.

5. Blomberg M, Tyrberg RB, Kjølhede P. Impact of maternal age on obstetric and neonatal outcome with emphasis on primiparous adolescents and older women: a Swedish medical birth register study. BMJ Open 2014;4:e005840.

6. Naqvi MM, Naseem A. Obstetrical risks in the older primigravida. J Coll Physicians Surg Pak 2004;14(5): 278-81.

7. Grotegut CA, Chisholm CA, Johnson LNC, et al. Medical and obstetric complications among pregnant women aged 45 and older. PLoS One 2014;9(4):e96237.

8. Luke B, Brown MB. Elevated risks of pregnancy complications and adverse outcomes with increasing maternal age. Human Reproduction 2007;22(5):1264-72.

9. Ngowa JD, Ngassam AN, Dohbit JS, et al. Pregnancy outcome at advanced maternal age in a group of African women in two teaching hospitals in Yaoundé, Cameroon. Pan Afr Med J 2013;14:134.

10. Nagarwal K, Chandrakanta, Gaur K, et al. Pregnancy outcome comparison in elderly and non elderly primigravida attending at mahila chikitsalaya, Jaipur (Rajasthan) India. International Multispecialty Journal of Health 2015;1(1):24-30.

11. Salem YS, Levy A, Wiznitzer A, et al. A significant linear association exists between advanced maternal age and adverse perinatal outcome. Arch Gynecol Obstet 2011;283(4):755-9.

12. Chibber R. Problems of older maternal age and pregnancy outcome. Bahrain Medical Bulletin 2004;26(3):105-9.

13. Bahtiyar MO, Funai EF, Rosenberg V, et al. Stillbirth at term in women of advanced maternal age in the United States: when could the antenatal testing be initiated? Am J Perinatol 2008;25(5):301-4.

14. Reddy UM, Ko CW, Willinger M. Maternal age and the risk of stillbirth throughout pregnancy in the United States. Am J Obstet Gynecol 2006;195(3):764-70. 
15. Eneh U, Fiebai PO, Anya SE, et al. Perinatal outcome among elderly nulliparae at the university of Port Harcourt teaching hospital. Nigerian Journal of Medicine 2004;13(1):44-7.

16. Weerasekera DS, Udugama SG. Pregnancy at 40 and over: a case-control study in a developing country. J Obstet Gynaecol 2003;23(6):625-7.
17. Delbaere I, Verstraelen H, Goetgeluk S, et al. Pregnancy outcome in primiparae of advanced maternal age. Eur J Obstet Gynecol Reprod Biol 2007;135(1):41-6. 